\title{
Relevancy of Law No. 10 Year 2009 about Tourism Towards Creative Economy as a New Platform Of Tourism Development in Indonesia
}

\author{
Akiko Nada Atsmara ${ }^{1}$, Bayu Mitra Adhyatma Kusuma ${ }^{2}$ \\ ${ }^{1}$ Burapha Business School, Faculty of Management and Tourism, Burapha University, Chon Buri, Thailand \\ ${ }^{2}$ Department of Public Administration, Faculty of Administrative Science, University of Brawijaya, Malang, \\ East Java, Indonesia
}

\begin{abstract}
It is necessary for human beings to become as creative as possible in order to maintain their viability. It can be said that human creativity emerges ever since the existence of humans on planet earth itself. Since year 2011 until now, Indonesia is the only country in the world having a big institution that uses the term creative economy that is the Ministry of Tourism and Creative Economy, formerly known as Ministry of Culture and Tourism. The emergence of the term Creative Economy itself hints that within the tourism development in Indonesia, the government is seeking to optimize creative economy sector, besides the country's natural and cultural heritage. On the other hand, up until now Indonesia still uses the Law No. 10 Year 2009 about Tourism as a platform in Indonesia's tourism development. This matter of course brings up challenges about several issues such as why does the government of Indonesia emphasizes on creative economy in their tourism development and is Law No. 10 Year 2009 about Tourism still relevant towards the development of creative economy in Indonesia. This research is based on a qualitative type, descriptive approach, and emphasize on the literature study.
\end{abstract}

Keywords: Law No. 10 Year 2009, Creative Economy, Tourism Development

\section{INTRODUCTION}

Humans are gifted with the ability to think in a much broad capacity and sense than other living beings making them the world dominator. Naturally, since their existence on planet earth, this ability is applied through creativity in order for humans to perform things easily and conveniently, fulfilling their life needs and to maintain their life continuance. Bilton (2007) explains that creativity must meet two criteria; it must produce something new, and it must produce intellectual property which is valuable or useful [1]. This applies not only to individual beings but also to organizations, companies, countries, etc. The UK Government has many times highlighted its creative skills as a source of competitive advantage. Until now, it appears that Indonesia is the only country in the world that has a government institution at the central level with the nomenclature of creative economy.

England itself as a country who first popularized the term creative industries as the core of the concept of creative economy, do not have an institution with the same name [2].

Corresponding Author:

Email : atsmara26@yahoo.com

Address : B-2 No. 34 street, Ampera Raya, South Jakarta, 12550
Instead their tourism ministry goes with the official name of the Department of Culture, Media and Sports (DCMS). The tourism department in Indonesia goes by the official name of the Ministry of Tourism and Creative Economy since 2011.

The creative economy, and the broad spectrum of creative industries that it encompasses, is an essential component of growth, employment and international trade in today's global age [3]. The term creative economy first appeared in 2001 in John Howkins's book about the relationship between creativity and economics. DeNatale and Wassal (2007) explains that the model that emerged from this creative economy initiative assessment of New England's creative economy identified three primary and interrelated components, namely the creative cluster, the creative workforce and creative communities. The creative cluster refers to industry, both commercial and non-profit; the creative workforce refers to occupation; and creative communities refer to geography [4].

Tourism in Indonesia is an important component of the Indonesian economy as well as a significant source of its foreign exchange revenues [5]. Indonesia was ranked 81st out 133 countries in the World Economic Forum Tourism Competitiveness Report for 2009, it has since 
risen to 74th place in 2011 [6]. In order to promote a further increase in the numbers of tourists, Her Minister planned to sharpen the country's profile as a multicultural, modern democratic country [7]. Despite its importance, Indonesia's tourism industry remains one of the country's most underexploited natural resources. Despite having the potential to cater to a broad range of tourist tastes from luxury beach holidays seekers to cultural and eco-tourists; tourism numbers have showed limp growth while neighboring countries have seen numbers soar [8]. Even the increasing tourist number for the past years, the growth is slow when compared to that of other members of ASEAN.

During the crisis in 1998, the tourist arrival targets in ASEAN member countries were almost the same; Malaysia 5.5 million, Thailand 7.7 million, Singapore 6.2 million and Indonesia 4.6 million. But Indonesia has now lagged far behind, with Malaysia's 2013 target reaching 26.8 million, Thailand 25 million, Singapore between 14.8 million and 15.5 million, while Indonesia 8.6 million [9]. There are some problems in the tourism sector of Indonesia. The infrastructure development in Indonesia especially in terms of transportation to reach tourism destinations are still considered insufficient [10] causing investors to be less keen in entering the market. Another issue regards to foreign ownership. The presence of foreign ownership leads to income from the tourism sector not fully contributing to the state income. Based on Presidential Regulation No. 36 Year 2010, foreign ownership can reach up to $49 \%$. Community lifestyle is also another issue. The first issue about the lifestyle is the hygienerelated, habits of the people who throw garbage/rubbish at will. The other problem is that the Indonesian people tend to be more proud if traveled in a foreign country than to travel in the country [11]. Other major issues regarding the tourism sectors in Indonesia mainly include natural disasters, security issues and natural resources conservation as a basis for tourism destination competitiveness and sustainability [5].

One of the major developments in tourism sector of Indonesia is ministry created in the cabinet reshuffle in 2011, which is the Ministry of Tourism and Creative Economy. Like any other ministries in the world, departments will experience a name change, but it appears until now that only Indonesia is the one who uses the creative economy concept in their tourism ministry despite that the concept was made by the British model. The development of the creative economy in the last decade was considered as an alternative solution, as well as global strategic in maintaining economic growth within the global economic slowdown.

According to Sugiarto (2013) Creative economy which is based on knowledge and creativity as a selling point has recently emerged as a force capable of winning the competition and economic development in Indonesia [12]. The Indonesian Government's seriousness in developing the creative economy is shown by the release of Presidential Instruction No. 6 Year 2009 on Development of Creative Economy. In addition, under the Presidential Regulation No. 92 Year 2011 on December 21, 2011, has established the Ministry of Tourism and Creative Economy with the vision to actualize the wellbeing and quality of life in Indonesia by moving the tourism and creative economy.

In this paper researcher would like to emphasize on why the creative economy is considered important towards the tourism development in Indonesia, and whether the tourism law is relevant towards this matter. This study is carried out to analyze the relevancy of Law No. 10 Year 2009 about Tourism towards creative economy as a new platform of tourism development in Indonesia. In this regard, this short study is structured as an attempt to fill the limitations of scientific information in order to provide insight, especially to policy makers who will develop a creative economy in Indonesia [13].

\section{METHODS}

This research use qualitative type of research, descriptive approach, and emphasize to literature study. The data collecting technique are using observation method and related text document.

\section{Data Collections}

Data was collected trough observation and document reviews. Observation was done by collecting and examining data and researching data on the circumstances and the actual reality to obtain answers to the problems. It used to recheck the information collected from the secondary data. The observation is to support the researcher to solve the problem and provide additional data that support the result. Document reviews was done by exploring and examining both historical and contemporary document. It is mean to obtain or to get accurate theories and references regarding data 
of the result findings by studying relevant rules, regulations, reports, documents and literatures.

\section{Data Analysis}

In this study, researcher use qualitative data analysis model of Miles and Huberman. Data analysis techniques of Miles and Huberman (1994) consist from four activities, namely: data collection, data reduction, data display, and conclusion [14].

\section{Data Collection}

An activity when researchers collect data needed for the study through the steps in the data collecting process.

\section{Data Reduction}

A process of selecting, focusing, simplifying, abstracting, and transforming the data that appears in written up field notes or transcription.

\section{Data Display}

An organized, compressed assembly of data and information that permits conclusion drawing and action Data display can be done in the form of a short description, charts and or relationships category.

\section{Conclusion}

An activity to conclude the records of the court where the initial conclusions presented are temporary and will be changed if they do not find strong evidence to support the next phase of data collection. Conclusion may not appear until data collection is finished, depending on size, coding, storage, and retrieval method used. The meanings of data have to be tested for their validity.

\section{RESULTS AND DISCUSSIONS}

\section{Creative Economy as a New Platform of Tourism Development in Indonesia}

In Indonesia, especially in the legislation in force, the term Creative Economy is used instead of Creative Industries, as by First Dictum Presidential Instruction No. 6 of 2009 on Development of Creative Economy is: "... economic activity based on creativity, skill and talent to create individual creativity and inventiveness of individuals that have economic value and affect the welfare of the Indonesian people" [2]. In 2010, the creative economy sector itself has contributed positively to the Indonesian economic growth in general, including to its GDP as well as the absorption of work force and balance of trade. In 2010, creative economy contributed approximately IDR 468.1 trillion, or equivalent to $7.29 \%$ of national GDP [15].

In the same year, creative economy also successfully absorbed approximately 8.6 million workforce, or equivalent to $7.9 \%$ from the total national amount. In comparison, the tourism sector absorbed $7.4 \%$ million people, or $6.9 \%$ of national work force. In terms of balance of trade, in 2010, the value of export was much higher than the value of import. The rate of growth of the creative economy in Indonesia itself continues to squirm, even, its development is higher than the national growth rate. Based on the creative economy statistical data released by the Central Statistics Agency of Indonesia (BPS), the rate of growth of the creative economy in 2013 reached $5.76 \%$ and the national growth rate of approximately $5.74 \%$. The sector is also able to absorb labor reached $11.872 \%$ of the total national employment [12].

Business prospects of the creative economy in Indonesia also shows that the more promising developments, this year the turnover of the creative economy in Indonesia is estimated to reach IDR 600 trillion. The increase in business this year Indonesia's creative economy grew on average $10 \%$ more than the 2012 which reached IDR 530 trillion, the economic contribution of the creative reaching $7 \%$ of the total GDP of Indonesia. Furthermore, there is a trend that creative economy absorbs greater number of workforce in Indonesia. In other words, more and more Indonesian people are becoming more dependent for their livelihoods to the creative economy. It was explained earlier that the Ministry of Tourism and Creative Economy has brought creative professionals together for conferences, exhibitions and festivals. One of the outstanding activity and attempt that is held annually since 2007 is the Pekan Produk Kreatif Indonesia (PPKI) or Indonesia Creative Products Week (ICPW). The ICPW event, as explained by Her Minister on a press conference in 2013 ICPW on 25th November 2013 is expected to provide a better understanding of the creative industries, public awareness of creative potential, expand networking among fellow actors and the creative parties can support sustainability. Other attempts done include national video contests such as the Eagle Documentary Awards, photography exhibitions such as Indonesia World Underwater Photo Exhibition, fashion and designers monthly/annually forums such as Jakarta Fashion Week or Indonesia Design and Craft Biennale 2013, and culinary events such as Indonesia Food and Hotel Expo 2013 that includes Indonesia Barista Competition, 
Indonesia Salon Culinaire, and other activities [16].

Creative Industries involve many stakeholders and target groups. Most of the target group are small-medium enterprises (SMEs), thus developing the creative industries will improve the welfare of society. Aside from events in terms of developing creative economy, the Ministry has also been cooperating and involves other stakeholders such as Association of Regional Development Banks (Asosiasi Bank Pembangunan Daerah or Asbanda) to provide access to capital for SMEs. To date, there are four cities that are firmly confirmed as a creative city in Indonesia, these are Yogyakarta, Solo, Bandung, and Pekalongan as a creative city, and on process of being confirmed by United Nations Educational, Scientific and Cultural Organization or UNESCO.

Her Ministry explained that this is one of our efforts to encourage cities in Indonesia to ripen preparations in infrastructure both physical and nonphysical to be a creative city known international community. Creative economy can build the image and identity of the nation in the international community. The wealth of local knowledge held by the Indonesian nation is a creative economic development capital. The creative economy here means a process that allows for an increase in value, either by making use of science or technology. Therefore all developments related to creative economy such as arts is considered a big potential in boosting Indonesian tourism to a whole new level.

These events that have been held are just some of the attempts of the Government in giving opportunities for the society to explore and develop the creative economy in Indonesia as a tourism platform. It can be seen that the Government supports, facilitates and open as wide opportunities for creative industry players in Indonesia. Surely the Government through the Ministry of Tourism and Creative Economy's acts are not limited in here, but continue to create further events as well as providing media to continue to improve creativity and productiveness in the creative economy as Indonesia's new tourism platform. Ministry of Tourism and Creative Economy also consistently provide and support groups or individuals deemed worthy to continue working and exhibiting their work nationally and globally.

The entry of the creative economy to the Ministry of Tourism is precisely to spur workers to better work of art that works of artists who highbrow art will be known internationally. With the collaboration of creative economy, the track for artists and creative beings are much more available and set formally. This means that the existence of artists will be more appreciated and valued. Thus, tourism is a forum to promote artwork and SMEs of the Indonesian society to a broader level, not to emasculate the freedom and exploration of the artists/creators. With the availability of creative economy in the structural organization, it is also expected that the creative works of the society will not only be exposed, but also more protected in terms of intellectual property rights, thus avoiding issues such as copyright or the brain drain.

Relevancy of Law No. 10 Year 2009 about Tourism towards the Development of Creative Economy in Indonesia

Law No. 10 Year 2009 provides rules for the tourist industry in Indonesia and provides for the rights and obligations of the community, of tourists and of the Government and Regional Government. It makes provision for the development of tourism, the determination of tourism strategic zones, the registration of tourism businesses, etc. The Law establishes the Indonesian Tourism Promotion Agency and Regional Tourism Promotion Agencies which shall be responsible for: improving Indonesia image in tourism; increase tourist visits and expenditures; collect funds from resources other than the State budget; etc. The Law further provides for the establishment of the Indonesia Tourism Industry Federation to support the development of the competitive tourism business sector. Law No. 10 Year 2009 consists of 16 chapters and 70 articles that explain the laws and regulations of all tourism-related attributes in the Republic of Indonesia. This section will discuss and analyze the articles on Law No. 10 Year 2009 that relates to the development of creative economy in Indonesia.

Chapter 2 about Basis, Function and Objective. Article 4 that states that tourism affairs shall be intended to: increase the economic growth, improve the people's welfare, eradicate poverty, overcome unemployment; preserve the nature, environment, and resources, promote the culture; raise the nation's image, foster a sense of patriotic, strengthen the nation identity and unity, and strengthen internation friendship. In the first point of the article, it is mentioned that the tourism affairs shall be intended to increase the economic growth. As 
mentioned in the previous sections that the creative economy is seen as a solution, an alternative, and a global strategy to maintain and increase economic development in the country. Recently on 23-24th January 2014, Her Minister was one of the Indonesian delegations attending in this year's World Economic Forum (WEF). WEF is the world's leading annual forum that addresses the development of the world economy and the development of a variety of important issues in the world both politically and security, climate change, sustainable development and culture and creativity. Ministry of Tourism and Creative Economy participated in Indonesian promotional events both in Malam Indonesia or Indonesian Night which has been held four times by the Ministry of Trade and Investment Coordinating Board (BKPM), as well as investment forums organized by BKPM. After four rounds held from, Indonesian Night has become a fixed event in the WEF program is eagerly awaited by participants as it has managed to become both a promotional event of Indonesian culinary diplomacy, as a platform to show the richness and creativity of Indonesian cultural heritage through traditional and contemporary performing arts, and to show the warm welcome of Indonesia [16].

As for the fourth point overcome unemployment, based on the statistical data released by $B P S$, the rate of growth of the creative economy in 2013 reached $5.76 \%$ and the national growth rate of approximately $5.74 \%$. The sector is also able to absorb labor reached $11.872 \%$ of the total national employment (Sugiarto, 2013). The PPKI or Indonesia Creative Products Week event itself for example, has involved more than 1.750 creative beings with visitors reaching the total of 85,000 people and total transactions reaching IDR 355 million (parekraf.go.id). In regards to the last point of the article, the implementation of PPKI makes creative meetings possible, collaboration, and expansion of the network in each community from different parts of Indonesia and business interaction to build strong creative and competitive business. Overall, PPKI is considered the first step for the players in the development of the creative economy sector to penetrate the global market. Compared to the previous Tourism Law No. 9 Year 1990, the article as part of the basis, function and objectives chapter is considered relevant towards the development of creative economy, but only in general. It mentions all attributes concerning tourism functions of a nation and applicable towards the development of creative economy itself. The previous law did not input economic growth as one of the intentions of the availability of tourism affairs. It was mainly involving expansion and maintaining the tourism attractions, increasing the social welfare, and encouraging the utilization of domestic products. The latest law also inputted more details and more articles as more improvements and programs are being developed in order to increase the nation's tourism.

Now, creative economy in tourism is considered as a new platform that has a selling point and increases the tourism competitiveness of the country. Indonesia is seen as a potential country to develop creative economy concept since the nation consists of diverse and multicultural identities. With the new formulated law creative economy was considered as a new alternative, solution and global strategy to increase economic growth, overcome unemployment, improve people's welfare, promote culture, raise the nation's image, and strengthen the nation's identity, unity and internation relations. Therefore article as a basis of the tourism affairs has been able to raise creative economy as the new platform of creative economy in Indonesia, though the article consists of overall general statements.

Chapter 4 about Tourism Affairs Development. Article 7 that states that tourism affairs development shall cover: tourism industry, tourism destination, marketing, and tourism institutionalism. The article provides clear guide on what tourism affairs development should cover when comparing to the previous law, that only mention about tourism development itself and the objectives without mentioning what should be covered. With this article the proper identification of what tourism affairs should cover will be able to make a vivid objective, strategy and programs in improving the nation's tourism. For example the concept of creative city explained previously is part of new development of the tourism destination. Four cities have been proposed to UNESCO to be acknowledged as Indonesia's creative cities. Her Minister explained that the four cities are chosen because they are considered to have advances in art, creative industry and design.

The development and penetration of creative economy have also attract and motivate the creative sectors from different regions to keep upgrading and improving their works in 
order to increase the competitiveness of each of their own provinces, cities, ethnics, etc. For example the events held by the Ministry in terms of exposing and developing creative economy showed the works and output of each different ethnic from different parts of Indonesia. Competitions held were also part of the triggers in improving the quantity and quality of creative human resource in the nation. This will not be apart from the fact that each region in Indonesia might be competing with each other and this does not only impact towards their own quality but also towards the their region as a tourism destination.

Chapter 6 about Tourism Business Article 17 that states that the Government and Regional Government shall develop and protect the micro, small and medium scale business and cooperatives in the tourism business sector by: prepare the policy on tourism business reserving for the micro, small, medium scale business, and cooperatives and facilitate the partnership of the micro, small, medium and cooperatives with the large scale business. Creative economy has a very broad scope. It relies on creativity and knowledge as well as information held by human resources as the main actor. Creative economy thus, has the advantage that it is not going to run out of raw materials like other activities in economy such as an industry. Creative economic activity also proved resilient towards the attack of an economic crisis. The future prospect of creative economy development towards tourism in Indonesia can be concluded to very promising since Indonesia has a large potential in improving it. It should also be based on productive and creative human resources, which makes the creative economy as a new source of competitiveness for Indonesia. Another additional advantage of creative economy is that it does not require huge capital. Many companies are using social media to market their services and products and proved its success.

Indeed the Government through the Ministry of Tourism and Creative Economy continues to improve the creative economy sector. The main Laws that base the ministry are Law No. 10 Year 2009, concerning tourism; Law No. 33 Year 2009, concerning cinematography; and Law No. 11 Year 2010, concerning cultural conservation. There are no specific regulations yet concerning creative economy in the tourism ministry itself. It was mentioned that the Government identified 14 subsectors of creative economy and the Ministry of Tourism and
Creative Economy added another subsector which was considered significant in the developing creative economy in Indonesia. But none of this is mentioned officially within the laws and no laws or regulations are provided to control the 14 subsectors specifically. As seen in the official website of the Ministrywww.parekraf.go.id- the 3 main laws that is the basis of the Ministry itself only covers tourism, cinematography and cultural conservation.

As the Ministry of Tourism is collaborated with creative economy sector, the Law No. 10 Year 2009 is still considered irrelevant towards creative economy as the new platform of tourism in Indonesia since there is no article that specifically mention about creative economy itself. However if the Government wishes to improve the creative economy sector, it should be taken for granted by inputting an article in the Law specifically provides greater portion to the creative economy. This will then clearly emphasize the creative economy as a platform with establishment of tourism in Indonesia, making it more relevant and have strong legal protection.

\section{CONCLUSION}

In the development of the creative economy in Indonesia under the new Ministry of Tourism and Creative Economy, the researcher identified two perspectives in the study. Based on the definition and creative economic activities listed in the Presidential Instruction With the inclusion of the development of creative economy activities in the Ministry of Tourism, the first perspective is that the development the creative economic activity is related tourism sector only. Therefore this perspective narrows the scope of the development of the creative economy.

The second perspective is the implications development of creative economy activities remains under the Ministry of Tourism and is associated with tourism activities. There is a reciprocal relationship between tourism activities with creative economy activities. Tourism activities can stimulate and promote economy activities and vice versa, where creative economy can also promote tourism activities. By looking through the Government's perspective, it seems they prefer the development creative economy activities that will develop towards tourism, as a new platform for its tourism development.

Whatever the perspectives are, there is still unclear portions of the development of 
creative economy within the Ministry of Tourism and Economy. The Law No. 10 Year 2009 as the basis foundation law concerning tourism still consists of generality. No specified terms regarding, mentioning, nor leading specifically towards creative economy itself. Therefore, the Indonesian Tourism Law No. 10 Year 2009 is not relevant towards creative economy as a new platform of the tourism development.

\section{REFERENCE}

[1]. Bilton, C. (2007). Management and Creativity: From Creative Industries to Creative Management. Oxford: Blackwell Publishing.

[2]. Antariksa, B. (2012). Konsep Ekonomi Kreatif: Peluang dan Tantangan Dalam Pembangunan Indonesia. Retrieved on November 13, 2013 from www.budpar.go.id.

[3]. Henry, C. and De Bruin, A. (2011). Entrepreneurship and the Creative Economy: Process, Practice, and Policy. Glos: Edward Elgar.

[4]. DeNatale, D. and Wassal GH. (2007). The Creative Economy: A New Definition. England: New England Foundation for the Arts.

[5]. Hakim, L., Soemarno, Hong, S.K. 2012. Challenges for conserving biodiversity and developing sustainable island tourism in North Sulawesi Province, Indonesia. Journal of Ecology and Field Biology. 35 (2): 61-71

[6]. World Economic Forum (WEF). (2012). The ASEAN Travel \& Tourism Competitiveness Report 2013. Retrieved on January 8, 2014 from www.weforum.com.

[7]. Deutsche Gesellschaft für Auswärtige Politik (DGAP). (2012). A Creative Economy as a Motor for Indonesia's Economic Growth. Retrieved on January 8, 2014 from www.dgap.org.

[8]. Global Business Guide (GBG) Indonesia. (2013). Indonesia's Tourism Industry and the Creative Economy. Retrieved on January 8, 2014 on www.gbgindonesia.com.

[9]. Abdussalam, A. (2013). Indonesia Achieves 2013 Foreign Tourist Target. Retrieved on January $8, \quad 2014$ from www.antaranews.com.

[10]. Satyagraha. (2013). Pengusaha Jepang Keluhkan Infrastruktur Kurang Memadai. Retrieved on January 26, 2014 from www.antaranews.com
[11]. Prawitasari, F. (2012). Jalan-jalan di Negeri Sendiri Lebih Nikmat. Retrieved on January 26, 2014 from www.travel.kompas.com.

[12]. Sugiarto, EC. (2013). PPKI 2013, Geliat Pengembangan Ekonomi Kreatif Indonesia. Jakarta: Cabinet Secretariat of the Republic of Indonesia.

[13]. Law No. 10 Year 2009 about Tourism

[14]. Miles, MB. and Hubberman AM. (1994). Qualitative Data Analysis: A Sourcebook of a New Method. London: Sage Publication.

[15]. Radiansyah, D. (2012). Strengthen- ing Creative Economy as Part of Economic Diplomacy in Indonesian Foreign Policy. Jakarta: Ministry of Foreign Affairs of the Republic of Indonesia.

[16]. Ministry of Tourism and Creative Economy RI. (2013). Kuliner Nusantara: Promosikan Pariwisata dan Ekonomi Kreatif Indonesia. Retrieved on January 29th, 2014 from www.parekraf.go.id. 